\title{
The role of the transradial approach in invasive diagnostics and treatment of peripheral arterial disease
}

\author{
Tomislav Krčmar*, \\ Ivica Benko, \\ Jadranka Daskijević \\ University Hospital Centre \\ "Sestre milosrdnice", Zagreb, \\ Croatia
}

RECEIVED:

February 10, 2016

ACCEPTED:

February 20, 2016

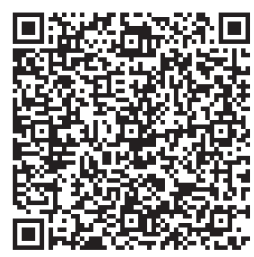

KEYWORDS: transradial access, peripheral artery disease, transluminal intervention. CITATION: Cardiol Croat. 2016;11(3-4):111. | DOI: http://dx.doi.org/10.15836/ccar2016.111

*ADDRESS FOR CORRESPONDENCE: Tomislav Krčmar, Klinički bolnički centar Sestre milosrdnice, Vinogradska 29, HR-10000 Zagreb, Croatia. / Phone: +385-99-520-0051 / E-mail: tomislav.krcmar@gmail.com

ORCID: Tomislav Krčma, http://orcid.org/0000-0003-4689-1673 • Ivica Benko, http://orcid.org/0000-0002-1878-0880 Jadranka Daskijević, http://orcid.org/0000-0001-6547-1098

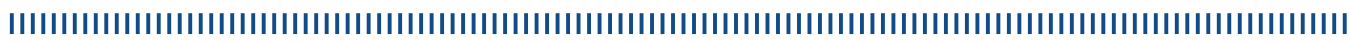

Transradial approach became frequent procedure in treatment of percutaneous coronary interventions while the same approach is still used rarely with the patients who need invasive angiology diagnostics. The main advantages of the transradial approach concerning the potential complications are generally very well known as well as the advantages in the means of comfort for the patient. ${ }^{1-3}$

In University Clinical Centre "Sestre milosrdnice" from 2011 transradial approach was used in total of 101 cases of invasive diagnostics or interventional treatment. In 32 situations it was used as one of the additional approaches within the main intervention on iliac arteries, whilst in 11 cases the transradial approach was the main the intervention on iliac arteries. For now, the transradial approach is mainly reserved for the interventions on renal and iliac arteries. Transradial approach is safe and reliable method for invasive diagnostics of peripheral arteries whilst the application of the interventions on arteries of the lower limb just recently started to be applied more often.

1. Coscas R, de Blic R, Capdevila C, Javerliat I, Goëau-Brissonniere 0, Coggia M. Percutaneous radial access for peripheral transluminal angioplasty. J Vasc Surg. 2015;61(2):463-8. DOI: http://dx.doi.org/10.1016/j.jvs.2014.07.009

2. Cortese B, Trani C, Lorenzoni R, Sbarzaglia P, Latib A, Tommasino A, et al. Safety and feasibility of iliac endovascular interventions with a radial approach. Results from a multicenter study coordinated by the Italian Radial Force. Int J Cardiol. 2014;175(2):280-4. DOI: http://dx.doi.org/10.1016/j.ijcard.2014.05.012

3. Ruzsa Z, Tóth K, Jambrik Z, Kovács N, Nardai S, Nemes B, et al. Transradial access for renal artery intervention. Interv Med Appl Sci. 2014;6(3):97103. DOI: $h$ ttp://dx.doi.org/10.1556/IMAS.6.2014.3.1 